\title{
ARHGEF5 Gene Product
}

National Cancer Institute

\section{Source}

National Cancer Institute. ARHGEF5 Gene Product. NCI Thesaurus. Code C132337.

A protein encoded by the ARHGEF5 gene. 